Arq. Bras. Med. Vet. Zootec., v.67, n.3, p.679-688, 2015

\title{
Effects of different extracts of the mushroom Agaricus blazei Murill on the hematologic profile of mice with Ehrlich tumor
}

[Efeitos de diferentes extratos do cogumelo Agaricus blazei Murill sobre o perfil hematológico de camundongos com tumor de Ehrlich]

\author{
D. Verçosa Júnior ${ }^{1}$, V.P. Ferraz ${ }^{2}$, E.R. Duarte ${ }^{3}$, N.J. F. Oliveira ${ }^{3}$, B. Soto-Blanco ${ }^{1}$, \\ G.D. Cassali ${ }^{4}$ M.M. Melo ${ }^{1} *$
}

\footnotetext{
${ }^{1}$ Escola de Veterinária - Universidade Federal de Minas Gerais - Belo Horizonte, MG ${ }^{2}$ Instituto de Ciências Exatas- Universidade Federal de Minas Gerais - Belo Horizonte, MG ${ }^{3}$ Instituto de Ciências Agrárias - Universidade Federal de Minas Gerais -Montes Claros, MG ${ }^{4}$ Instituto de Ciências Biológicas-Universidade Federal de Minas Gerais -Belo Horizonte, MG
}

\begin{abstract}
The aim of this study was to investigate the effect of the mushroom Agaricus blazeii Murril (ABM) extracts on the hematological profile of Swiss mice bearing an Ehrlich solid tumor. Three fractions (total extract, polysaccharides, and supernatant) of ABM extracts obtained by four methods (ultrasonic or water bath, at $\mathrm{pH} 4$ or $\mathrm{pH} 7$ ) were administered to mice over 21 days. Polysaccharide solutions were analyzed by gas and liquid chromatography that showed both mannose and glucose concentrations. The method of extraction influenced the degree of glucose polymerization and the mannose/glucose relationship. The treatment with $\mathrm{ABM}$ supernatant at $\mathrm{pH} 7$ and water bath was associated with reduced concentrations of leukocytes and lymphocytes and altered the percentage of CD4+ and CD8+ lymphocytes in Ehrlich tumor-bearing mice. The treatment with the ABM extract in water bath and ultrasound at $\mathrm{pH} 4$ resulted in lower lymphocyte counts, regardless of tumor presence, and greater granulocyte values in mice with Ehrlich tumor than in controls. We concluded that different fractions and methods of extraction of $A$. blazei produced differing blood profiles in mice inoculated with the Ehrlich tumor.
\end{abstract}

Keywords: mouse, Ehrlich solid tumor, polysaccharides, hematological profile

\section{RESUMO}

O objetivo deste estudo foi investigar o efeito de diferentes extratos do cogumelo Agaricus blazeii Murril $(A B M)$ sobre o perfil hematológico de camundongos Swiss portadores de tumor de Ehrlich sólido. Três frações (extrato total, polissacarídeos e sobrenadante) dos extratos de ABM foram obtidas por quatro métodos (sonificador, banho-maria, em pH 4 ou pH 7) e administradas para camundongos durante 21 dias. Soluções de polissacarídeos foram analisadas por cromatografia gasosa e líquida, que mostraram concentrações de glucose e manose. O método de extração influenciou o grau de polimerização da glicose e a relação manose/glucose. O tratamento com o sobrenadante de ABM (em pH 7 e banho-maria) estava associado com reduzidas concentrações de leucócitos e linfócitos, além de alterar a porcentagem de linfócitos $\mathrm{CD} 4+$ e CD8+ em camundongos portadores de tumor sólido de Ehrlich. $O$ tratamento com extratos de ABM, obtidos tanto em banho-maria como no sonificador em $\mathrm{pH} 4$, resultou nas mais baixas contagens de linfócitos, independentemente da presença do tumor, e nos maiores valores de granulócitos em camundongos com tumor de Ehrlich. Conclui-se que os diferentes métodos de extração com as respectivas frações de A. blazei são capazes de intereferir no perfil hematológico de camundongos com tumor sólido de Ehrlich.

Palavras-chave: camundongo, tumor sólido de Ehrlich, polissacarídeos, perfil hematológico

Recebido em 21 de abril de 2014

Aceito em 27 de março de 2015

*Autor para correspondência (corresponding author)

E-mail: mariliamm@ufmg.br 


\section{INTRODUCTION}

Cancer is the second greatest cause of death in humans in Brazil and many other countries (WHO, 2013). Research into the origin and evolution of tumors and potential treatments can help to determine appropriate diagnosis diagnosis and their prognosis and to establish best treatment practices. Current treatment protocols employing antineoplastic agents, surgery, radiation, and chemotherapy have serious side effects. These can be reduced with hormone replacement therapies and treatments to strengthen the immune system, but it is essential to seek new drugs that have less aggressive effects on the patient (Suffredini, 2002). In this way, extensive studies have been conducted evaluating the antitumor effect of natural compounds.

Active substances in basidiomycetes may be within the cell wall, and the disruption of cellulose barriers can aid in the release of substances and in the discovery of new compounds contained in fungi (Yamanakaa et al., 2012). Methods of extraction using acid or breakdown of hemicellulose with ultrasound could be valuable in improving the efficacy of the anti-neoplastic action.

The basidiomycete Agaricus blazei Murrill (ABM), syn. Agaricus subrufescens Peck, Agaricus brasiliensis, according to Wasser et al. (2002), commonly known as the sun mushroom, is marketed fresh for consumption and in syrups, solutions, and capsules in Brazil (ANVISA, 2003). Substances extracted from this mushroom, including 1.6-beta-glucan, 1.3-betaglucan, active hemi-cellulose compounds, and anti-tumor organic substance Mie, aid the treatment of neoplasm by increasing the number and activity of natural killer (NK) cells and titration of immunoglobulins (IgM, IgG) and Interleukin-1 (Itho et al., 1997; Ohno et al., 2001; Takeshi et al., 2001; Gennari et al., 2002; Oshiman et al., 2002). Methanolic extracts of immature and mature $\mathrm{ABM}$, although differing in concentrations of phenolic compounds, show similar antioxidant activity, except for the chelating capacity of ferrous ions, which is greater in the cups of ripe fruit (Soares et al., 2009).
The pharmacological effects of ABM must be elucidated in relation to the extraction method and extract components, including polysaccharides. The aim of this study was to evaluate the hematological profile of mice with and without an Ehrlich tumor treated with ABM extracts.

\section{MATERIALS AND METHODS}

Extracts were obtained from $3 \mathrm{~kg}$ of dehydrated ABM purchased from a commercial producer in São José do Rio Preto City, São Paulo, Brazil. After identification by morphology and DNA sequence analyses, a sample was deposited in the herbarium of the Institute of Biological Sciences of the Federal University of Minas Gerais (BHCB 97946). The heavy metal and pesticide content was assessed. Six hundred gram subsamples of dried mushroom were powered to 40 mesh for aqueous extraction and fractioning.

For the preparation of aqueous extracts, powered $\mathrm{ABM}$ was kept dry and protected from light in sterile amber glass vials. $150 \mathrm{~g}$ aliquots were mixed into $1000 \mathrm{~mL}$ distilled water or $2 \%$ glacial acetic acid, producing neutral $(\mathrm{pH} 7)$ or acidic (pH 4) suspensions, respectively. The process was repeated, and each suspension was held in a water bath at $60^{\circ} \mathrm{C}$ for $3 \mathrm{~h}$ under agitation or in an ultrasonic bath at $37^{\circ} \mathrm{C}$ for $30 \mathrm{~min}$. Following extraction, the solutions were passed through a paper filter. Four aqueous extracts were prepared: $60^{\circ} \mathrm{C}$ water bath extractions at $\mathrm{pH} 7$ and $\mathrm{pH} 4$, and $37^{\circ} \mathrm{C}$ ultrasonic bath extractions at pH 7 and $\mathrm{pH} 4$.

Five hundred $\mathrm{mL}$ of each extract were added to $2000 \mathrm{~mL}$ of ethanol to precipitate polysaccharides. Following precipitation, $50 \mathrm{~mL}$ of each sample was homogenized and placed in a Falcon-type tube and centrifuged for $10 \mathrm{~min}$ at $20^{\circ} \mathrm{C}$ at $300 \mathrm{~g}$. The sediment was separated and desiccated at ambient temperature, weighed, and the percentage of polysaccharides was determined.

The sediments were dissolved in $2 \%$ acetic acid solution or distilled water to a volume of $500 \mathrm{~mL}$ to create $\mathrm{ABM}$ polysaccharide solutions. The solutions were concentrated in a rotary evaporator at $80^{\circ} \mathrm{C}$, speed six, for removal of the ethanolic fraction. Distilled water or $2 \%$ acetic acid was added to make up the volume to $500 \mathrm{~mL}$ 
and to create the ABM extracts for use in the experiments. Total extract, supernatant, and polysaccharide solutions were created for each of the 4 extraction methods, to obtain twelve solutions. Monosaccharides present in the polysaccharide solutions were determined by gas chromatography of alditol acetates produced by hydrolysis with trifluoroacetic acid, reduction with sodium borohydride sodium, and acetylation. Thus, the ABM solute and relative content of glucose and mannose was determined. The size of the polysaccharide molecules was measured by liquid chromatography using size exclusion or gel permeation chromatography, using standard polystyrene column GPC-803D $300 \mathrm{x} 8 \mathrm{~mm}$, dimethylformamide as mobile phase, flow rate of $1.0 \mathrm{~mL} / \mathrm{min}$, ultra violet detector at $270 \mathrm{~nm}$, and shot volume of $20 \mu \mathrm{L}$.

The experiment used 192 non-isogenic female Swiss mice Mus musculus, 60 days old, weighing 30-45g, obtained from the Ezequiel Dias Foundation Biotery. The in vivo protocol was approved by the Ethics Committee on Animal Experimentation (CETEA) of UFMG.

Mice were randomly separated into 4 groups of 48 for assessment of the 4 extraction methods. Each extraction group consisted of 2 groups of 24 mice, with or without a tumor, designated GI and GII, respectively, further separated into 4 treatment groups of six. Mice were held in cages $(40 \times 45 \times 25 \mathrm{~cm})$ for a 10 day adaptation period prior to the trials.

To prepare for the induction of a solid tumor, Ehrlich tumor cells were maintained in ascitic form in Swiss albino mice, and transferred weekly into healthy animals to preserve the Ehrlich tumor in vivo. On day 7 post-inoculation, $3 \mathrm{~mL}$ of ascitic fluid was collected from the donor mouse in a disposable syringe. The ascitic fluid was placed in a Falcon tube and centrifuged at $300 \mathrm{~g}$ for $3 \mathrm{~min}$ to separate the supernatant. The volume was increased to $3 \mathrm{~mL}$ with $0.9 \%$ saline at room temperature and stirred slowly, and the procedure was repeated three times until the supernatant became translucent (Guerra, 1983; Verçosa Junior et al., 2007).
For analysis of tumor viability, $1.98 \mathrm{~mL}$ of $0.9 \%$ saline solution was added to $0.02 \mathrm{~mL}$ of cell suspension from the ascetic fluid and homogenized. Aliquots of $0.1 \mathrm{~mL}$ of this mixture were added to an equal volume of $0.1 \%$ Trypan blue. A cell count was performed in four external quadrants of a Neubauer hemocytometer. Counts showed $95.04 \%$ of cells were viable (translucent) and $4.69 \%$ nonviable (blue stained), yielding $5 \mathrm{x}$ $10^{8}$ viable tumor cells per $1.0 \mathrm{~mL}$ suspension.

Over the course of 21 days, distilled water, total extract, supernatant, or polysaccharide solution were administered to mice daily by gavage, after $3 \mathrm{~h}$ without food or water, at $2.5 \mathrm{~g} / \mathrm{kg}$ of body weight (BW) (Table 1).

On day 10 , tumor cell solution $(0.05 \mathrm{~mL})$ was injected into GII mice between the plantar pads of the left rear foot. At 21 days mice were anesthetized with intramuscular ketamine (50mg/g BW) and xylazine (10mg/g BW) and $0.3 \mathrm{~mL}$ of blood was collected (Anderson, 1998). Samples were placed in microtubes containing $0.005 \mathrm{~mL}$ of a $10 \%$ solution of diamine tetra acetic acid (EDTA) for automated electronic blood count (ABX ABC Vet, ABX Diagnostics, Montpellier, France). The evaluated blood parameters were erythrocytes (RBC), packed cell volume (PCV), hemoglobin ( $\mathrm{Hb})$, mean corpuscular volume (MCV), mean corpuscular hemoglobin $(\mathrm{MCH})$, mean corpuscular hemoglobin concentration (MCHC), platelets (Plq), total leukocytes (Leuko), lymphocytes (Lymph), monocytes (MO) and granulocytes (GRA).

After hematologic analyzes, $0.05 \mathrm{~mL}$ of blood from mice was mixed to obtain a pool of blood for each group. Samples were incubated with monoclonal antibodies to count CD4+ cells (auxiliary lymphocytes) and CD8+ cells (cytotoxic/suppressor lymphocytes) by flow cytometry.

The normality of data distribution was evaluated by the Kolmogorov-Smirnov test. Parametric data were processed by analysis of variance (ANOVA) with the Duncan test, with a significance level of 5\%, and the Kruskal-Wallis test was used for non-parametric data. 
Table 1. Distribution of 192 mice without (GI) or with (GII) Ehrlich solid tumor groups $(\mathrm{n}=24)$ and in treatment groups $(n=6)$ treated for 21 days with Agaricus blazei extracts produced in a water bath or ultrasonic bath at $\mathrm{pH} 4$ or $\mathrm{pH} 7$, to total solution, polysaccharide solution or supernatant or distilled water Treatments for four experiments with two tumor groups with four treatments

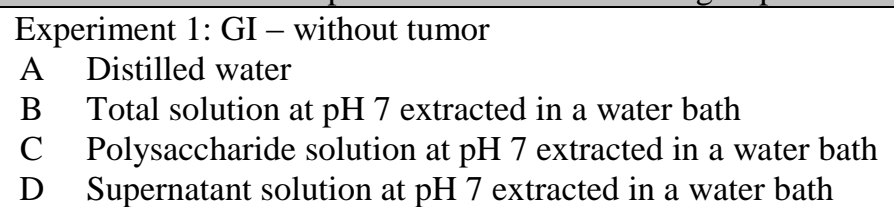

\section{Experiment 1: GII - with Ehrlich tumor}
A Distilled water
B Total solution at $\mathrm{pH} 7$ extracted in a water bath
C Polysaccharide solution at $\mathrm{pH} 7$ extracted in a water bath
D Supernatant solution at $\mathrm{pH} 7$ extracted in a water bath
Experiment 2: GI - without tumor
E Distilled water
F Total solution at $\mathrm{pH} 4$ extracted in a water bath
$\mathrm{G}$ Polysaccharide solution at $\mathrm{pH} 4$ extracted in a water bath
$\mathrm{H}$ Supernatant solution at $\mathrm{pH} 4$ extracted in a water bath

Experiment 2: GII - with Ehrlich tumor

E Distilled water

F Total solution at $\mathrm{pH} 4$ extracted in a water bath

G Polysaccharide solution at $\mathrm{pH} 4$ extracted in a water bath

$\mathrm{H}$ Supernatant solution at $\mathrm{pH} 4$ extracted in a water bath
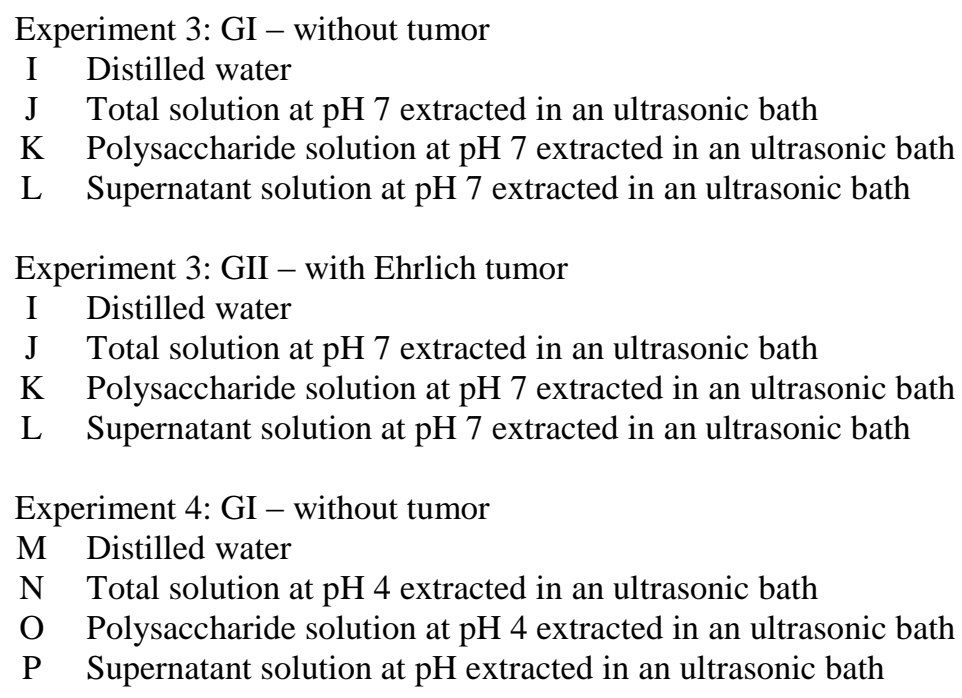

\section{Experiment 4: GII - with Ehrlich tumor}

M Distilled water

$\mathrm{N}$ Total solution at $\mathrm{pH} 4$ extracted in an ultrasonic bath

$\mathrm{O}$ Polysaccharide solution at $\mathrm{pH} 4$ extracted in an ultrasonic bath

$\mathrm{P}$ Supernatant solution at $\mathrm{pH} 4$ extracted in an ultrasonic bath 


\section{RESULTS AND DISCUSSION}

Analysis showed that the extracted polysaccharides consisted of glucopyranoside ( $\beta$-glucan) as expected, and also included mannopyranoside (mannan) and/or gluco/mannopyranoside (glucanmannan). These results are important, since, to date, most authors cite only glucose in the aqueous extracts of ABM. Park et al. (2003) reported differing values of $\beta$-glucan in samples of this fungus, and suggested that differences in cultivation may affect $\mathrm{ABM}$ quantities.

The method of extraction affected the ratio of glucose to mannose. The polysaccharide content was affected by the extraction method, and this is relevant, since $\beta$-glucan in ABM has been shown to modulate the immune system (Oshiman et al., 2002).

Analyses of the polysaccharide solutions showed that the extraction methods provided polysaccharides with differing degrees of glucose polymerization (Table 2).

Table 2. Mean polymerization degree and molecular weight of polysaccharides from Agaricus blazei aqueous extraction at $\mathrm{pH} 4$ or $\mathrm{pH} 7$ in ultrasonic bath or water bath

\begin{tabular}{lcc}
\hline Extraction method & $\begin{array}{c}\text { Molecular } \\
\text { weight }\end{array}$ & $\begin{array}{c}\text { Polymerization } \\
\text { degree }\end{array}$ \\
\hline water bath at pH 7 & 3.151 & 18 \\
water bath at pH 4 & 2.348 & 13 \\
ultrasonic bath at pH 7 & 1.864 & 10 \\
ultrasonic bath at pH 4 & 1.763 & 10 \\
\hline
\end{tabular}

Water bath extraction at $\mathrm{pH} 7$ showed the highest mean value of molecular weight (MW) of polymers $(3.151 \mathrm{~g} / \mathrm{mol})$, followed by water bath extraction at $\mathrm{pH} 4(2.348 \mathrm{~g} / \mathrm{mol})$. The extractions in the ultrasonic bath produced lower MW values (Table 2). An influence of both the method of extraction and acidity was observed. The lesser degree of polymerization measured in extracts obtained in the ultrasonic bath in acidic solution show this method to be more efficient in breaking the polymers. Extraction method and acidity may act synergistically.

The variation in molecular size was greater in $\mathrm{pH}$ 4 solutions than $\mathrm{pH} 7$ solutions. These results are relevant, since intestinal absorption of $\mathrm{ABM}$ molecules may be influenced by molecular weight. Thus, the clinical effects of ABM treatments may differ depending on the administration route. These substances administered orally may be affected by stomach $\mathrm{pH}$ or by hepatic metabolism, resulting in modification of their initial structure.

For the most efficient extraction of glucans from ABM, the effects of the form of extraction on the concentration of polysaccharides should be considered. The differing $\mathrm{pH}$ and extraction methods influenced the proportions of mannose/glucose as well as the polysaccharide concentration. The presence of mannose is of fundamental clinical relevance and suggests further studies of extracts of this fungus.

Yamanaka et al. (2012) used anti- $\beta$-glucans and nuclear magnetic resonance analysis to investigate the immunomodulatory activity of ABM extracts and characterized the polysaccharide as 1.6- $\beta$-glucans and a small proportion as $1.3-\beta$-glucans. These polysaccharides strongly induced the production of cytokines in spleen and dendritic cells derived from bone marrow. Cytokine production was significantly reduced in dendritic cells derived from animals with dectin-1 deficiency. In addition, a binding assay revealed that the polysaccharides of ABM can be recognized by dectin-1, an important receptor for 1.3 - $\beta$-glucans, providing evidence of $\mathrm{ABM}$ immune system stimulation.

No differences were found among treatment groups for erythrocyte and platelet counts, packed cell volume, or hematimetric indices (P>0.05, Tables 3, 4, 5, and 6). All variables were within normal limits for Mus musculus (Moore, 2000). According to Korekane et al. (2003), the presence of an Ehrlich tumor can promote cachexia with hepatic and splenic lesions. The spleen plays an important role in the maturation of blood cells and promotes phagocytosis of damaged erythrocytes in mice (Moore, 2000). Neither tumor presence nor the ABM treatment affected erythrocyte values, platelet count, or hematimetric indices of mice during the evaluation period. Future studies of the effects of ABM treatment in animals with an Ehrlich tumor should extend over a longer time period to evaluate possible hematological alterations. 
In the treatment with the $\mathrm{pH} 7$ water bath extracts, GI-D and all the mice with tumor showed significantly lower leukocyte and lymphocyte values compared with the other groups (Table 3, P<0.05). GII-A, GII-B and GII$\mathrm{C}$ mice showed significantly greater numbers of circulating granulocytes and lower numbers of lymphocytes than GI-A and GI-B mice.

With the $\mathrm{pH} 4$ water bath extracts, significantly lower lymphocyte counts $\left(5.1 \times 10^{3} / \mathrm{mm}^{3}\right)$ were also observed in GII-E mice than in GI-E, showing reduction of these cells with tumor presence (Table $4, \mathrm{P}<0.05$ ). Mice without tumor (GI-E) presented lower numbers of granulocytes $\left(0.43 \times 10^{3} / \mathrm{mm}^{3}\right)$ than GII-E $\left(1.60 \times 10^{3} / \mathrm{mm}^{3}\right)$, demonstrating inflammatory activity in animals with an Ehrlich tumor.
The increase in the leukocyte count in tumorbearing animals was to be expected (Dagli, 1992a, b). However, in this study lower levels were observed in the GII mice and in the GI group treated with the supernatant of the water bath ABM extract at pH 7. Verçosa Junior et al., (2004) reported an increase in young neutrophils but also did not observe increase of total leukocytes in animals inoculated with an Ehrlich tumor.

The differences in leukocyte count may be related to an inflammatory reaction to the Ehrlich tumor (Dagli, 1992a, b) and the presence of immunostimulating substances in $A B M$ polysaccharides, such as 1.6 - $\beta$-glucan and $1.3-\beta$ glucan (Gennari et al., 2002).

Table 3. Mean values and standard deviation of erythrocytes (RBC), packed cell volume (PCV), hemoglobin (Hb), mean corpuscular volume (MCV), mean corpuscular hemoglobin $(\mathrm{MCH})$, mean corpuscular hemoglobin concentration (MCHC), platelets (Plq), total leukocytes (Leuko), lymphocytes (Lymph), monocytes (MO) and granulocytes (GRA) in mice without (GI) or with (GII) Ehrlich solid tumor treated with distilled water (A) or with total extract (B), polysaccharide solution (C) or supernatant (D) of extracts of Agaricus blazei produced in $\mathrm{pH} 7$ water bath at $60^{\circ} \mathrm{C}$

\begin{tabular}{|c|c|c|c|c|c|c|c|c|c|c|c|}
\hline 产 & 曾 & 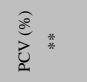 & 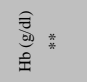 & 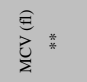 & 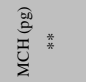 & 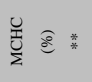 & 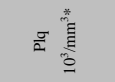 & 急 & 言言 & 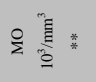 & 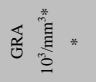 \\
\hline GI - A & $10.70 \pm 1.0$ & $47.7 \pm 2.7$ & $15.3 \pm 2.1$ & $45.4 \pm 2.8$ & $14.2 \pm 1.2$ & $31.5 \pm 3.1$ & $621.23 \pm 76.8$ & $10.4 \pm 2.9^{\mathrm{a}}$ & $9.8 \pm 2.8^{\mathrm{a}}$ & $0.17 \pm 0.12$ & $0.43 \pm 0.21^{\mathrm{b}}$ \\
\hline GI - B & $10.00 \pm 0.3$ & $46.7 \pm 1.2$ & $15.6 \pm 0.6$ & $46.7 \pm 0.8$ & $15.6 \pm 0.3$ & $33.5 \pm 0.4$ & $532.3 \pm 36.8$ & $9.9 \pm 3.2^{\mathrm{a}}$ & $9.4 \pm 3.1^{\mathrm{a}}$ & $0.15 \pm 0.08$ & $0.45 \pm 0.22^{\mathrm{b}}$ \\
\hline GI - C & $9.32 \pm 0.7$ & $43.8 \pm 2.4$ & $15.1 \pm 0.6$ & $47.4 \pm 1.1$ & $16.2 \pm 0.8$ & $34.2 \pm 1.1$ & $630.0 \pm 154.5$ & $10.5 \pm 5.4^{\mathrm{a}}$ & $9.3 \pm 6.0^{\mathrm{a}}$ & $0.22 \pm 0.07$ & $1.02 \pm 0.99^{\mathrm{ab}}$ \\
\hline GI - D & $10.00 \pm 0.8$ & $45.5 \pm 1.6$ & $15.8 \pm 0.5$ & $46.2 \pm 1.9$ & $15.8 \pm 1.0$ & $34.0 \pm 1.0$ & $528.3 \pm 48.8$ & $6.2 \pm 1.9^{\mathrm{b}}$ & $5.6 \pm 1.9^{\mathrm{b}}$ & $0.16 \pm 0.06$ & $0.43 \pm 0.13^{b}$ \\
\hline GII - A & $10.40 \pm 0.9$ & $45.4 \pm 2.1$ & $14.9 \pm 1.3$ & $45.3 \pm 0.9$ & $14.5 \pm 0.4$ & $31.9 \pm 0.5$ & $553.1 \pm 94.4$ & $6.9 \pm 3.1^{\mathrm{b}}$ & $5.1 \pm 2.6^{\mathrm{b}}$ & $0.24 \pm 0.14$ & $1.60 \pm 0.69^{\mathrm{a}}$ \\
\hline GII - B & $9.80 \pm 1.4$ & $45.8 \pm 5.2$ & $14.3 \pm 1.6$ & $46.0 \pm 0.9$ & $14.6 \pm 0.5$ & $31.8 \pm 0.6$ & $641.7 \pm 238.3$ & $5.8 \pm 1.7^{\mathrm{b}}$ & $4.3 \pm 1.4^{\mathrm{b}}$ & $0.14 \pm 0.06$ & $1.37 \pm 0.64^{\mathrm{a}}$ \\
\hline GII - C & $9.60 \pm 3.2$ & $46.0 \pm 3.2$ & $15.1 \pm 4.9$ & $47.4 \pm 1.1$ & $13.4 \pm 2.8$ & $28.2 \pm 5.7$ & $593.8 \pm 184.7$ & $7.2 \pm 4.5^{\mathrm{ab}}$ & $5.5 \pm 3.6^{\mathrm{b}}$ & $0.18 \pm 0.17$ & $1.51 \pm 0.90^{\mathrm{a}}$ \\
\hline GII - D & $9.90 \pm 0.6$ & $44.2 \pm 1.5$ & $14.4 \pm 0.6$ & $45.6 \pm 0.6$ & $14.5 \pm 0.5$ & $31.9 \pm 0.8$ & $501.0 \pm 108.9$ & $5.9 \pm 1.5^{\mathrm{b}}$ & $4.6 \pm 1.2^{\mathrm{b}}$ & $0.23 \pm 0.08$ & $1.14 \pm 0.40^{\mathrm{ab}}$ \\
\hline
\end{tabular}

Different lowercase letters in the same column indicate significant difference $(P \leq 0.05) . *$ ANOVA with Duncan's test; ** ANOVA with Kruskal-Wallis test.

Table 4. Mean values and standard deviation of erythrocytes (RBC), packed cell volume (PCV), hemoglobin (Hb), mean corpuscular volume (MCV), mean corpuscular hemoglobin $(\mathrm{MCH})$, mean corpuscular hemoglobin concentration (MCHC), platelets (Plq), total leukocytes (Leuko), lymphocytes (Lymph), monocytes (MO) and granulocytes (GRA) in mice without (GI) or with (GII) Ehrlich solid tumor treated with distilled water (E) or with total extract $(\mathrm{F})$, polysaccharide solution $(\mathrm{G})$, or supernatant $(\mathrm{H})$ of extracts of Agaricus blazei produced in $\mathrm{pH} 4$ water bath at $60^{\circ} \mathrm{C}$

\begin{tabular}{|c|c|c|c|c|c|c|c|c|c|c|c|}
\hline $\begin{array}{l}\text { 产 } \\
\text { 产 }\end{array}$ & 品 & 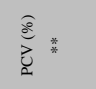 & 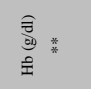 & $\begin{array}{l}\subseteq \\
\sum_{\Sigma}^{*}\end{array}$ & 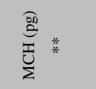 & 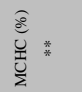 & 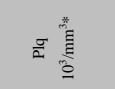 & 竧蒡 & 言商商 & 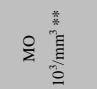 & 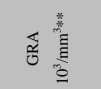 \\
\hline GI - E & $10.74 \pm 1.0$ & $47.7 \pm 2.7$ & $15.3 \pm 2.1$ & $45.3 \pm 2.8$ & $14.2 \pm 1.2$ & $31.5 \pm 3.1$ & $621.2 \pm 76.8$ & $10.4 \pm 2.9^{\mathrm{ab}}$ & $9.8 \pm 2.8^{\mathrm{a}}$ & $0.17 \pm 0.12$ & $0.43 \pm 0.21^{b}$ \\
\hline GI - F & $10.00 \pm 0.7$ & $45.0 \pm 1.4$ & $15.2 \pm 0.5$ & $46.0 \pm 0.9$ & $15.2 \pm 0.7$ & $33.1 \pm 1.2$ & $631.6 \pm 214.0$ & $11.9 \pm 3.9^{\mathrm{a}}$ & $10.1 \pm 4.4^{\mathrm{a}}$ & $0.22 \pm 0.19$ & $1.47 \pm 0.91^{\mathrm{ab}}$ \\
\hline GI - G & $9.85 \pm 0.8$ & $44.3 \pm 2.2$ & $15.3 \pm 0.7$ & $46.5 \pm 1.8$ & $15.5 \pm 0.7$ & $33.5 \pm 0.6$ & $510.3 \pm 109.3$ & $10.5 \pm 4.7^{\mathrm{ab}}$ & $9.6 \pm 4.3^{\mathrm{a}}$ & $0.23 \pm 0.26$ & $0.68 \pm 0.43^{b}$ \\
\hline GI - $\mathrm{H}$ & $10.20 \pm 0.6$ & $46.5 \pm 2.2$ & $15.9 \pm 1.0$ & $46.3 \pm 1.5$ & $15.5 \pm 0.3$ & $33.4 \pm 1.0$ & $489.0 \pm 104.2$ & $8.4 \pm 4 . .^{\text {ab }}$ & $7.5 \pm 4.5^{\mathrm{ab}}$ & $0.20 \pm 0.07$ & $0.65 \pm 0.52^{\mathrm{b}}$ \\
\hline GII - E & $10.36 \pm 0.9$ & $45.36 \pm 2.1$ & $14.98 \pm 1.3$ & $45.2 \pm 0.9$ & $14.5 \pm 0.4$ & $31.9 \pm 0.5$ & $553.1 \pm 94.4$ & $6.9 \pm 3.1^{\mathrm{b}}$ & $5.1 \pm 2.9^{\mathrm{b}}$ & $0.24 \pm 0.14$ & $1.60 \pm 0.69^{\mathrm{a}}$ \\
\hline GII - F & $10.97 \pm 2.4$ & $47.33 \pm 3.4$ & $15.7 \pm 2.2$ & $45.3 \pm 2.3$ & $14.45 \pm 1.2$ & $31.8 \pm 1.5$ & $583.2 \pm 118.5$ & $8.5 \pm 3.4^{\text {ab }}$ & $5.7 \pm 2.3^{\mathrm{ab}}$ & $0.43 \pm 0.28$ & $2.31 \pm 1.15^{\mathrm{a}}$ \\
\hline GII - G & $10.10 \pm 0.6$ & $45.17 \pm 2.0$ & $14.6 \pm 0.7$ & $46.3 \pm 0.8$ & $14.5 \pm 0.6$ & $31.3 \pm 1.1$ & $516.5 \pm 148.1$ & $10.7 \pm 4.5^{\text {ab }}$ & $7.9 \pm 4.5^{\mathrm{ab}}$ & $0.35 \pm 0.31$ & $2.08 \pm 0.57^{\mathrm{a}}$ \\
\hline GII - H & $10.23 \pm 0.6$ & $46.5 \pm 2.4$ & $15.1 \pm 0.9$ & $46.2 \pm 0.7$ & $14.7 \pm 0.26$ & $31.9 \pm 0.5$ & $570.5 \pm 184.7$ & $8.9 \pm 3.6^{\mathrm{ab}}$ & $6.3 \pm 3.0^{\mathrm{ab}}$ & $0.33 \pm 0.14$ & $2.23 \pm 0.66^{\mathrm{a}}$ \\
\hline
\end{tabular}

Different lowercase letters in the same column indicate significant difference $(P \leq 0.05)$. * ANOVA with Duncan's test; ** ANOVA with Kruskal-Wallis test. 
There were no significant differences in total leukocyte count between GI and GII with ultrasonic bath-extracted treatments (Table 5 and 6). GII mice treated with solutions at $\mathrm{pH} 7$ showed significantly lower values of lymphocytes than control tumor-free mice.

All GII treatment groups and the total (GI-J) and polysaccharide (GI-K) solutions of ultrasonic bath-extracted $\mathrm{ABM}$ at $\mathrm{pH} 7$ in GI mice were associated with increased granulocyte values (Table 5, $\mathrm{P}<0.05$ ). In the $\mathrm{pH} 4$ extraction trial, mice with an Ehrlich tumor presented significantly higher granulocyte numbers than observed in tumor-free mice from all groups (Table 6, $\mathrm{P}<0.05$ ).

Table 5. Mean values and standard deviation of erythrocytes (RBC), packed cell volume (PCV), hemoglobin (Hb), mean corpuscular volume (MCV), mean corpuscular hemoglobin $(\mathrm{MCH})$, mean corpuscular hemoglobin concentration (MCHC), platelets (Plq), total leukocytes (Leuko), lymphocytes (Lymph), monocytes (MO) and granulocytes (GRA) in mice without (GI) or with (GII) Ehrlich solid tumor treated with distilled water (I) or with total extract (J), polysaccharide solution (K), or supernatant (L) of extracts of Agaricus blazei produced in $\mathrm{pH} 7$ ultrasonic bath

\begin{tabular}{|c|c|c|c|c|c|c|c|c|c|c|c|}
\hline 气̆ & 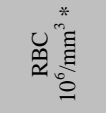 & $\underbrace{2}$ & $\begin{array}{l}\hat{\bar{\theta}} \\
\text { क्⿹ } \\
\text { : }\end{array}$ & $\begin{array}{l}\widehat{E} \\
己^{*} * \\
\Sigma^{*}\end{array}$ & 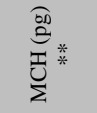 & 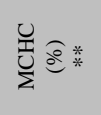 & 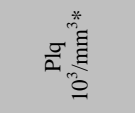 & 产 & 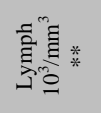 & 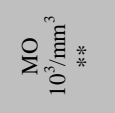 & 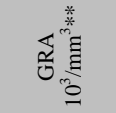 \\
\hline GI - I & $10.70 \pm 1.0$ & $47.8 \pm 2.7$ & $15.3 \pm 2.1$ & $45.4 \pm 2.8$ & $14.2 \pm 1.2$ & $31.5 \pm 3.1$ & $621.3 \pm 76.8$ & $10.4 \pm 2.9$ & $9.8 \pm 2.8^{\mathrm{a}}$ & $0.17 \pm 0.12$ & $0.43 \pm 0.21^{b}$ \\
\hline GI - J & $10.10 \pm 1.2$ & $47.0 \pm 3.4$ & $15.5 \pm 1.3$ & $46.83 \pm 1.6$ & $15.4 \pm 0.9$ & $32.7 \pm 0.9$ & $622.2 \pm 160.9$ & $9.1 \pm 1.3$ & $7.7 \pm 1.3^{\mathrm{ab}}$ & $0.25 \pm 0.17$ & $1.13 \pm 0.83^{\mathrm{a}}$ \\
\hline GI - K & $10.20 \pm 1.0$ & $44.5 \pm 3.3$ & $15.5 \pm 0.8$ & $46.3 \pm 1.5$ & $15.3 \pm 1.0$ & $33.0 \pm 1.5$ & $565.2 \pm 180.0$ & $8.22 \pm 3.8$ & $6.7 \pm 2.7^{\mathrm{ab}}$ & $0.27 \pm 0.25$ & $1.23 \pm 1.57^{\mathrm{a}}$ \\
\hline GI - L & $9.50 \pm 0.9$ & $45.7 \pm 2.4$ & $15.1 \pm 1.7$ & $47.3 \pm 0.8$ & $15.8 \pm 1.1$ & $33.5 \pm 1.8$ & $619.0 \pm 187.0$ & $7.0 \pm 4.2$ & $6.7 \pm 4.1^{\mathrm{ab}}$ & $0.15 \pm 0.12$ & $0.12 \pm 0.14^{\mathrm{b}}$ \\
\hline GII - I & $10.40 \pm 0.9$ & $45.4 \pm 2.1$ & $14.8 \pm 1.3$ & $45.3 \pm 0.9$ & $14.5 \pm 0.4$ & $31.9 \pm 0.5$ & $553.1 \pm 94.4$ & $6.9 \pm 3.1$ & $5.1 \pm 2.6^{\mathrm{b}}$ & $0.24 \pm 0.14$ & $1.60 \pm 0.69^{\mathrm{a}}$ \\
\hline GII - J & $10.60 \pm 0.7$ & $46.2 \pm 1.6$ & $15.0 \pm 0.9$ & $44.3 \pm 1.8$ & $14.2 \pm 0.6$ & $31.8 \pm 0.7$ & $528.2 \pm 78.9$ & $8.3 \pm 2.5$ & $5.1 \pm 0.8^{\mathrm{b}}$ & $0.27 \pm 0.21$ & $2.99 \pm 1.93^{\mathrm{a}}$ \\
\hline GII -K & $9.30 \pm 1.8$ & $44.7 \pm 5.7$ & $13.9 \pm 2.1$ & $46.8 \pm 1.6$ & $15.0 \pm 0.7$ & $32.2 \pm 0.9$ & $532.8 \pm 131.8$ & $8.2 \pm 4.0$ & $6.3 \pm 3.3^{\mathrm{b}}$ & $0.29 \pm 0.15$ & $1.66 \pm 0.67^{\mathrm{a}}$ \\
\hline GII -L & $9.80 \pm 0.9$ & $47.2 \pm 5.8$ & $14.6 \pm 1.5$ & $46.8 \pm 0.4$ & $14.9 \pm 0.3$ & $31.9 \pm 0.3$ & $448.7 \pm 155.6$ & $7.2 \pm 1.4$ & $5.6 \pm 1.3^{\mathrm{b}}$ & $0.20 \pm 0.08$ & $1.44 \pm 0.37^{\mathrm{a}}$ \\
\hline
\end{tabular}

Table 6. Mean values and standard deviation of erythrocytes (RBC), packed cell volume (PCV), hemoglobin (Hb), mean corpuscular volume (MCV), mean corpuscular hemoglobin (MCH), mean corpuscular hemoglobin concentration (MCHC), platelets (Plq), total of leukocytes (Leuko), lymphocytes (Lymph), monocytes (MO) and granulocytes (GRA) in mice without (GI) or with GII) Ehrlich solid tumor (treated with distilled water (M) or with total extract (J), polysaccharide solution (K), or supernatant (L) of extracts of Agaricus blazei produced in $\mathrm{pH} 4$ ultrasonic bath

\begin{tabular}{|c|c|c|c|c|c|c|c|c|c|c|c|}
\hline 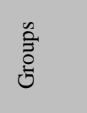 & U. & $\begin{array}{l}\delta^{\circ} \\
z^{*}\end{array}$ & 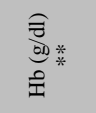 & $\begin{array}{l}\widehat{E} \\
己^{*} *\end{array}$ & \begin{tabular}{l} 
ब0 \\
\multirow{2}{0}{} \\
$\underbrace{*} *$ \\
$\underbrace{*}$
\end{tabular} & $\sum_{\Sigma}^{U} \varrho^{\varrho} *$ & 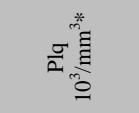 & 窇 & 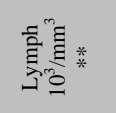 & 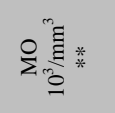 & 胥 \\
\hline GI - M & $10.7 \pm 1.0$ & $45.8 \pm 2.7$ & $15.3 \pm 2.1$ & $45.4 \pm 2.8$ & $14.2 \pm 1.2$ & $31.5 \pm 3.1$ & $621.3 \pm 76.8$ & $10.4 \pm 2.9$ & $9.8 \pm 2.8^{\mathrm{a}}$ & $0.17 \pm 0.12$ & $0.43 \pm 0.21^{b}$ \\
\hline GI - N & $9.6 \pm 1.3$ & $43.2 \pm 2.9$ & $14.5 \pm 1.1$ & $45.7 \pm 2.3$ & $15.2 \pm 1.1$ & $33.2 \pm 1.1$ & $735.8 \pm 210.9$ & $10.4 \pm 4.4$ & $9.2 \pm 4.1^{\mathrm{ab}}$ & $0.36 \pm 0.27$ & $0.85 \pm 0.67^{\mathrm{b}}$ \\
\hline GI - O & $10.73 \pm 0.7$ & $45.3 \pm 3.1$ & $16.5 \pm 0.8$ & $46.0 \pm 1.6$ & $15.4 \pm 0.6$ & $33.3 \pm 1.0$ & $560.2 \pm 88.2$ & $8.1 \pm 3.6$ & $7.0 \pm 3.5^{\mathrm{abc}}$ & $0.30 \pm 0.11$ & $0.79 \pm 0.57^{\mathrm{b}}$ \\
\hline GI - P & $9.5 \pm 0.6$ & $45.7 \pm 2.2$ & $15.1 \pm 1.2$ & $47.0 \pm 1.7$ & $15.9 \pm 1.0$ & $33.7 \pm 1.2$ & $531.0 \pm 139.8$ & $8.5 \pm 1.7$ & $7.6 \pm 1.9^{\mathrm{abc}}$ & $0.15 \pm 0.07$ & $0.55 \pm 0.38^{\mathrm{b}}$ \\
\hline GII -M & $10.4 \pm 0.9$ & $45.4 \pm 2.1$ & $14.9 \pm 1.3$ & $45.7 \pm 0.9$ & $14.5 \pm 0.4$ & $31.9 \pm 0.5$ & $553.1 \pm 94.4$ & $6.9 \pm 3.1$ & $5.1 \pm 2.6^{\mathrm{c}}$ & $0.24 \pm 0.14$ & $1.60 \pm 0.69^{\mathrm{ab}}$ \\
\hline GII - N & $10.3 \pm 1.9$ & $46.2 \pm 6.1$ & $14.9 \pm 2.1$ & $46.5 \pm 1.2$ & $14.6 \pm 0.9$ & $31.3 \pm 1.3$ & $826.50 \pm 408.9$ & $9.7 \pm 4.5$ & $6.7 \pm 4.6^{\text {abc }}$ & $0.35 \pm 0.27$ & $2.72 \pm 1.20^{\mathrm{a}}$ \\
\hline GII - O & $9.2 \pm 0.9$ & $43.7 \pm 2.9$ & $14.3 \pm 1.0$ & $45.7 \pm 1.4$ & $14.4 \pm 0.5$ & $31.7 \pm 0.8$ & $512.5 \pm 171.8$ & $7.3 \pm 3.1$ & $5.6 \pm 2.5^{\mathrm{bc}}$ & $0.24 \pm 0.18$ & $1.48 \pm 0.59^{\mathrm{ab}}$ \\
\hline GII - P & $8.9 \pm 2.9$ & $45.2 \pm 2.1$ & $14.9 \pm 4.2$ & $46.3 \pm 1.8$ & $14.5 \pm 0.6$ & $31.4 \pm 1.3$ & $476.5 \pm 220.4$ & $8.5 \pm 3.6$ & $6.2 \pm 3.2^{\mathrm{abc}}$ & $0.38 \pm 0.11$ & $1.93 \pm 0.62^{\mathrm{ab}}$ \\
\hline
\end{tabular}
test.

Lin et al. (2007) reported that B-glucan from the fungus Grifola frondosa increased cell production in bone marrow, as well as the proliferation of granulocytes and monocytes in the umbilical cord. Bernardshaw et al. (2007), in a study using human white blood cells, described increased expression of adhesion molecules for monocytes and granulocytes treated with ABM extracts. These studies are corroborated by the higher granulocyte values found in the heath groups treated with total extract (GI J) and polysaccharide solution (GI K) of ABM produced in $\mathrm{pH} 7$ ultrasonic bath that was observed in this present study (Table 5).

The CD4+ lymphocyte concentrations were not shown to be influenced by the presence of an Ehrlich tumor when comparing untreated GI and 
GII. However, the administration of ABM was associated with differences in these values. In mice treated with water bath-extracted ABM solutions at $\mathrm{pH} 7$, greater numbers of this circulating cell were observed. In mice with a tumor, the treatment with the supernatant showed a $15.34 \%$ increase in these values compared to untreated (Table 7). The administration of the water bath-extracted $\mathrm{ABM}$ at $\mathrm{pH} 4$ total solution (GII F) decreased in $15.3 \%$ this concentration compared to untreated animals with a tumor (GII E) (Table 7).

Table 7. Percent of CD4+ and CD8+ lymphocytes in a pool of blood from mice without (GI) or with (GII) Ehrlich solid tumor treated with distilled water or with total extract, polysaccharide, or supernatant of Agaricus blazei extracts at $\mathrm{pH} 4$ or $\mathrm{pH} 7$ produced in a water bath at $60^{\circ} \mathrm{C}$ or ultrasonic bath

\begin{tabular}{|c|c|c|c|}
\hline \multicolumn{2}{|c|}{ Treatments } & $\begin{array}{c}\text { CD4+ lymphocytes } \\
\%\end{array}$ & $\begin{array}{c}\text { CD8+ lymphocytes } \\
\%\end{array}$ \\
\hline \multicolumn{4}{|c|}{ Experiment 1: pH 7 water bath extract } \\
\hline GI-A & Distilled water & 31.26 & 10.83 \\
\hline GII-A & Distilled water & 31.62 & 18.12 \\
\hline GII-B & Total solution & 32.11 & 20.24 \\
\hline GII-C & Polysaccharide solution & 35.07 & 24.02 \\
\hline \multicolumn{4}{|c|}{ Experiment 2: pH 4 water bath extract } \\
\hline GI-E & Distilled water & 31.26 & 10.80 \\
\hline GII-E & Distilled water & 31.62 & 18.00 \\
\hline GII-F & Total solution & 26.79 & 22.21 \\
\hline GI-I & Distilled water & 31.26 & 10.83 \\
\hline GII-I & Distilled water & 31.62 & 18.30 \\
\hline GII-J & Total solution & 31.73 & 24.45 \\
\hline GII-K & Polysaccharide solution & 28.32 & 16.94 \\
\hline GII-L & Supernatant solution & 31.24 & 17.99 \\
\hline \multicolumn{4}{|c|}{ Experiment 4: $\mathrm{pH} 4$ ultrasonic bath extract } \\
\hline GI-M & Distilled water & 31.26 & 10.87 \\
\hline GII-M & Distilled water & 31.62 & 18.27 \\
\hline GII-N & Total solution & 34.05 & 19.68 \\
\hline
\end{tabular}

In untreated mice, the mean percent of CD8+ lymphocytes in the four extraction methods was higher in GII when compared to GI. In groups with a tumor, the administration of polysaccharide water bath-extracted solution at pH 7 (GII C) showed a 24.2\% increase compared to untreated mice (GII A). For total (GII-J) and supernatant ultrasonic bath-extracted solutions, the percentages of this lymphocyte were higher than with other treatments (Table 7).

The Ehrlich tumor induces significant changes in the early host immune system with the suppression response reducing the $\mathrm{T}$ helper cell and NK cell activity. The tumor also induces a humoral response that is less effective in controlling tumor growth. In the maturation process, CD4+ $\mathrm{T}$ lymphocytes (helpers) can produce effectors and memory cells. These lymphocytes play a role in cellular immunity, secreting cytokines that can induce B lymphocytes and immunoglobulins secretion, as well as activation of the complement and of macrophages (Segura et al. 1997, 2000; Morales et al. 1999).

The results of the present study showed lower tumor growth with administration of ABM supernatant solutions (unpublished data). Correlation between the percent of CD8+ cells and the thickness of the footpad was observed. Gao et al. (2007) have reported higher rates of apoptosis of tumor cells in vitro with exposure to $\mathrm{ABM}$ fractions that increase lymphocyte activity. 
The CD8+ cells are mainly effective against viruses and tumor cells and can release TNF-a and IFN-g that acts synergistically. This cell can constitute a distinct population of $\mathrm{T}$ cells that can suppress both humoral and cellular responses. These lymphocytes also produce specific proteins that bind directly to tumor cells and induce apoptosis (Morales et al. 1999; Moore, 2000).

\section{CONCLUSION}

Glucopyranoside mannopyranoside and gluco/ mannopyranoside were detected in evaluated ABM extracts. The method of extraction influenced the degree of glucose polymerization and the mannose/glucose relationship. Neither the administration of ABM extracts nor tumor presence was associated with alterations in the erythrogram or platelet level during the evaluated period. Different fractions and methods of extraction of $\mathrm{ABM}$ influenced the leukogram profiles and can alter of the percent of CD4+ and CD8+ lymphocytes in Ehrlich tumor-bearing mice.

\section{ACKNOWLEDGEMENTS}

We thank the Fundação de Amparo à Pesquisa de Minas Gerais (FAPEMIG) and Conselho Nacional de Desenvolvimento Científico e Tecnológico (CNPq) of Brazil for providing financial support. The authors are also grateful to Coordenação de Aperfeiçoamento de Pessoal de Nível Superior (CAPES, Brazil) and Pro-reitoria de Pesquisa da Universidade Federal de Minas Gerais.

\section{REFERENCES}

BERMARDSHAW, S.; LYBERG, T.; HETLAND, G. et al. Effect of an extract of the mushroom Agaricus blazei Murill on expression of adhesion molecules and production of reative oxigen species monocytes and granulocites in human whole blood ex vivo. APMIS, v.115, p.719-725, 2007.

DAGLI, M.L.Z., GUERRA, J.L., SALDIVA, .PH.N. An experimental study on the lymphatic dissemination of the solid Ehrlich tumor in mice. Braz. J. Vet. Res. Anim. Sci., v.29, p.97-103, 1992a.
DAGLI, M.L.Z.; SOMA, M.; GUERRA, J.L., SALDIVA; P.H.N. Lymphatic dissemination in neoplasia: determination of nuclear volume and DNA content of primitive and regional lymph node Ehrlich tumor cells. Braz. J. Vet. Res. Anim. Sci., v.29, p. 267-271, 1992b.

GAO, L.; SUN, Y.; CHEN, C. et al. Primary mechanism of apoptosis induction in a leukemia cell line by fraction FA-2-b- $\beta$ prepared from the mushroom Agaricus blazei Murill. Braz. J. Med. Biol. Res., v.40, p.1545-1555, 2007.

GENNARI, J.L.; VERONESI, R.; GENNARI, M.S. Uso do cogumelo Agaricus sylvaticus como complemento terapêutico em pacientes com câncer de mama e metástase pulmonar. Rev. Bras. Med., v. 59, p.537-538, 2002.

GUERRA, J.L. Aspectos do processo inflamatório em camundongos portadores de Tumor de Ehrlich. 1983. 87f. Tese (Doutorado) Faculdade de Medicina Veterinária e Zootecnia, Universidade de São Paulo, São Paulo, SP.

ITHO, H.; SHIMURA, K.; KAWADE, M. Antitumor effects of a new polysaccharideprotein complex (ATOM) prepared from Agaricus blazei (Iwade Strain 101) "Himematsutake" and its mechanisms in tumorbearing mice. Anticancer Res., v.17, p.277-284, 1997.

KOREKANE, $\quad$ H.; NISHIKAWA, A.; IMAMURA, K. Mechanisms mediating metabolic normalities in the livers of Ehrlich tumor-bearing mice. Arch. Biochem. Biophys., v.412, p.216-222, 2003.

LIN, H.; CHEUNG, S.W.Y.; NESIN, M. et al. Enhancement of umbilical Cord blood cell hematopoiesis by Mitake beta-glucano is mediated by granulocite colony-stimulating factor production. Clin. Vac. Immunol., v.14, p. 21-27, 2007.

MOORE, D.M. Hematology of rabbits. In: FELDMAN, B.F., ZINKL, J.G., JAIN, N.C., SCHALM, S. (Eds) Veterinary hematology. Philadelphia: Lippincolt Willians \& Wilkins, 2000. P.1100-1106.

MORALES, J.R.; VÉLEZ, D.; SUBIZA, J.L. Ehrlich tumor stimulates extramedullar hematopoiesis in mice without secreting identifiable colony-stimulating factors and without engagement of host $\mathrm{T}$ cells. Exp. Hematol., v.27, p.1757-1767, 1999. 
OHNO, N.; FURUKAWA, M.; MINURA, N.N. et al. Antitumor beta glucano from the cultured fruit body of Agaricus blazei. Biol. Pharm. Bulletin, v.24, p.820-828, 2001.

OSHIMAN, K.; FUJIMIYA, Y.; EBINA, T. et al. Orally administered beta-1,6-D-polyglucose extracted from Agaricus blazei results in tumor regression in tumor-bearing mice. Planta Med., v.68, p.610-614, 2002.

PARK, Y.K.; IKEGAKI, M.; ALENCAR, M. et al. Determinação da concentração de b-glucano em cogumelo Agaricus blazei Murill por método enzimático. Ciênc. Tecnol. Alim., v.23, p.312$316,2003$.

PROCEDIMENTOS sobre cogumelos. ANVISA, 2003. Informe Técnico $n^{\circ} 6$, de 31 de janeiro de 2003. Available: <http://portal.anvisa.gov.br/wps/wcm/connect/1a 0bbb804bd8274dbbccfbbc0f9d5b29/Informe+T $\% \mathrm{C} 3 \%$ A9cnico+n\%C2\%BA+6.pdf?MOD=AJPE RES>. Acessed: 19 of June 2013.

SEGURA, J.A.; BARBERO, L.G.; MÁRQUEZ, J. Ehrlich ascities tumor unbalances splenic cell populations and reduces responsiveness of $\mathrm{T}$ cell to Staphylococcus aureus enterotoxin B stimulation. Immunol. Lett., v.74, p.111-115, 2000 .

SEGURA, J.A.; BARBERO, L.G.; MÁRQUEZ, $\mathrm{J}$. Early tumor effect on splenic T lymphocytes in mice. FEBS Lett., v.414, p.1-6, 1997.

SOARES, A.A.; SOUZA, C.G.M.; DANIEL, F.M. et al. Antioxidant activity and total phenolic content of Agaricus brasiliensis (Agaricus blazei Murril) in two stages of maturity. Food Chem., v.112, p.775-781, 2009.
SULFFREDINI, I.B. A review the physiological basis of cancer diseases and the search for new chemotherapeutics. The importance of the Brazilian biodiversity. J. Inst. Health Sci., v.20, p.103-115, 2002.

TAKESHI, T.; KIMURA, Y.; OKADA, H. Isolation of an antitumor compound from Agaricus blazei Murrill and its mechanism of action. J. Nutr., v.131, p.1409-1413, 2001.

VERÇOSA JÚNIOR, D.; MELO, M.M.; DANTAS-BARROS, A.M. et al. Quadro hematológico e peso do baço de camundongos com tumor de Ehrlich na forma sólida tratados com Agaricus blazei. Rev. Bras. Farmacog., v.14, p.32-34, 2004.

VERÇOSA JÚNIOR, D.; MELO, M.M.; CASSALI, G.D. et al. Influência de Agaricus blazei Murril sobre o tumor sólido de Ehrlich e linfonodos poplíteos de camundongos. Arq. Bras. Med. Vet. Zootec., v.59, p.150-154, 2007.

WORLD cancer Day. World Health Organization, 2013. Disponível em: <http://www.who.int/cancer/en/>. Acessado em: 05 de June de 2013.

YAMANAKAA, D.; TADAA, R.; ADACHIA, Y. et al. Agaricus brasiliensis-derived $\beta$-glucans exert immunoenhancing effects via a dectin-1dependent pathway. Inst. Immunopharmacol., v.13, p.311-319, 2012.

WASSER, S.P.; DIDUK, M.Y.; AMAZONAS, M. et al. Is a widely cultivated culinarymedicinal royal sun Agaricus (the himematsutake mushroom) indeed Agaricus blazei Murril? Int. J. Med. Mushr., v.4, p. 267290, 2002. 